\title{
ANTICORPOS CONTRA BRUCELAS LISAS EM SUÍNOS ABATIDOS NO SEMIÁRIDO DA PARAÍBA
}

\author{
S.S. Azevedo ${ }^{1}$, R.M. Oliveira ${ }^{1}$, M.L.C.R. Silva ${ }^{1}$, \\ M.M.S. Macedo ${ }^{1}$, C.S.A.B. Santos ${ }^{2}$, C.J. Alves ${ }^{1}$, S.S.S. Higino ${ }^{1}$
}

${ }^{1}$ Universidade Federal de Campina Grande, Centro de Saúde e Tecnologia Rural, Unidade Acadêmica de Medicina Veterinária, Av. Universitária, s/no, CEP 58700-970, Patos, Paraíba, Brasil. E-mail: sergio@vps. fmvz.usp.br

\section{RESUMO}

\begin{abstract}
O objetivo do presente trabalho foi determinar a frequência de anticorpos contra brucelas lisas em suínos abatidos no semiárido da Paraíba. Para tanto, foram utilizadas 306 amostras de soros de suínos abatidos no matadouro público de Patos, Estado da Paraíba, Nordeste do Brasil. Para a detecção de anticorpos contra brucelas lisas, o teste do antígeno acidificado tamponado (AAT) foi empregado como teste de triagem, e a prova do 2-mercaptoetanol (2-ME) foi empregada como método confirmatório. Dos 306 suínos testados, três (0,98\%; IC 95\% = 0,20\% - 2,84\%) foram positivos para anticorpos contra brucelas lisas no teste de AAT, e dois $(0,65 \%$; IC $95 \%=0,08 \%-2,34 \%)$ foram confirmados no 2-ME, sendo um animal com título 200 e um com título 25.
\end{abstract}

PALAVRAS-CHAVE: Brucelose animal, anticorpos, frequência, abate.

\section{ABSTRACT}

DETECTIONOF ANTIBODIESAGAINSTSMOOTHBRUCELLA INSWINESLAUGHTEREDIN THESEMIARID REGIONOF PARAÍBASTATE, BRAZIL. The aim of this research was to determine the frequency of antibodies against smooth Brucella in swine slaughtered in the semiarid region of the state of Paraíba, Brazil. Three hundred and six serum samples from swine slaughtered in the public slaughterhouse of the city of Patos were used. For the detection of antibodies against smooth Brucella, the Rose Bengal plate test (RBPT) was applied as a screening method and the 2-mercaptoethanol test as a confirmatory method. Of the 306 swine tested, $3(0.98 \% ; 95 \% \mathrm{CI}=0.20 \%-2.84 \%)$ were positive for antibodies against smooth Brucella at RBPT, and $2(0.65 \%$; 95\% CI $=0.08 \%-2.34 \%)$ were confirmed in the 2-mercaptoethanol; 1 animal presented titer 200 and 1 titer 25.

KEY WORDS: Animal brucellosis, antibodies, frequency, slaughter.

A brucelose suína é uma zoonose de evolução preferencialmente crônica, provocada pela Brucella suis (biovares 1, 2 e 3) e caracterizada, em porcas gestantes, por transtornos da reprodução, incluindo abortamento, nascimento de leitões fracos e mortalidade neonatal e, nos varrões, por orquite e epididimite, assim como por inflamações articulares, causando enormes prejuízos à suinocultura (ALTON, 1990). Os suínos também podem ser infectados por outras espécies de Brucella sp., incluindo a B. abortus, agente causador da brucelose bovina (CRAWFORD et al., 1990).

A infecção causa prejuízos consideráveis à suinocultura, tais como queda na produção de leitões e eliminação de animais de alto valor zootécnico. $\mathrm{O}$ caráter zoonótico da doença deve ser considerado, e os indivíduos mais expostos ao risco da infecção representam aqueles que lidam diretamente com os animais, como veterinários efuncionários de granjas, bem como aqueles que lidam com produtos de origem suína, como operários de frigoríficos (GODFROID; KÄSBOHRER, 2002).

No Brasil, há vários relatos da ocorrência de suínos soropositivos para brucelose. MATOs et al. (2004), no Estado de Goiás, examinaram, com o emprego do Card Test, 829 amostras de sangue de suínos de 40 granjas, e verificaram que apenas uma $(0,12 \%)$ amostra foi positiva, reforçando que na produção tecnificada e com um rigoroso esquema de sanidade a brucelose suína não é um problema. Em contrapartida, em estudo realizado

${ }^{2}$ Universidade de São Paulo, Faculdade de Medicina Veterinária e Zootecnia, Departamento de Medicina Veterinária Preventiva e Saúde Animal, São Paulo, SP, Brasil. 
por Roxo et al. (1996), na região Sul de São Paulo, foram utilizadas 42 amostras de sangue de uma propriedade sem os devidos cuidados de sanidade, e em 37 (88,09\%) houve resultado positivo no teste de Rosa Bengala. FreITAS et al. (2001), em Belém do Pará, analisaram 139 amostras de soros de suínos de diversas procedências com as provas do Card Test e soroaglutinação rápida em placa eobservaramque $42,2 \%$ dosanimais apresentaram anticorpos contra brucelas lisas.

Considerando a inexistência de dados acerca da brucelose suína no Estado da Paraíba, bem como a possibilidade de transmissão do agente aos seres humanos, principalmente aqueles expostos ao risco de infecção, o objetivodopresentetrabalhofoideterminarafrequência de anticorpos contra brucelas lisas em suínos abatidos no matadouro público de Patos, Estado da Paraíba.

Foram utilizados 306 suínos abatidos no período de abril a junho de 2007, totalizando 124 machos e 182 fêmeas. A rotina das colheitas foi estabelecida para todas as quartas-feiras, quintas-feiras e sextasfeiras, uma vez que os suínos são abatidos somente nesses dias. As colheitas foram efetuadas em todos os animais abatidos no período. Não foi possível separar os animais por idadee/ou procedência, pois não havia registros oficiais dos proprietários nem de suas propriedades no matadouro.

O sangue foi colhido em tubos de ensaio no momento da sangria, realizada com o animal em decúbito lateral esquerdo ou direito, logo após a insensibilização. Em seguida as amostras foram encaminhadas ao Laboratório de Doenças Transmissíveis (LDT) do Centro de Saúde e Tecnologia Rural (CSTR) da Universidade Federal de Campina Grande (UFCG), em Patos, $\mathrm{PB}$, onde foram centrifugadas para a separação do coágulo e obtenção do soro. Os soros sanguíneos foram estocados em microtubos de polipropileno previamente identificados e mantidos congelados a $-20^{\circ} \mathrm{C}$ até a realização das provas sorológicas.

Para a pesquisa de anticorpos contra brucelas lisas, o teste do Antígeno Acidificado Tamponado (AAT) foi utilizado como prova de triagem, e os soros que reagiram positivamente foram submetidos à prova do 2-mercaptoetanol (2-ME) (BRASIL, 2001). Para a verificação de uma possível associação entre sexo dos animais e soropositividade para brucelose, foi utilizado o teste exato de Fisher (ZAR, 1999), com nível de significância de 5\%. Para a análise, foi utilizado o programa EpiInfo versão 6.04 .
Na prova do AAT, dos306 suínos analisados, três foram soropositivos, resultando em uma soroprevalência de $0,98 \%$ (IC 95\% = 0,20\% - 2,84\%) (Tabela 1). Dos 124 machos, um $(0,81 \%$; IC $95 \%=0,02 \%-4,41 \%)$ foi soropositivo, enquanto duas $(1,10 \%$; IC $95 \%=$ $0,13 \%-3,91 \%)$ das 182 fêmeas foram soropositivas.

Na prova do 2-ME, das três amostras reagentes no AAT, duas foram confirmadas como positivas (Tabela 1 ), resultando em uma soroprevalência de $0,65 \%$ (IC 95\% = 0,08\% - 2,34\%). Uma amostra foi positiva na diluição 1:200 e outra na diluição 1:25. Todas as amostras positivas no 2-ME foram de fêmeas, e não foi observada diferença significativa na proporção de soropositivos entre machos e fêmeas $(p=0,516)$.

Apesar de o teste do 2-ME não ser padronizado para o uso no diagnóstico da brucelose suína, há um forte indício de que suínos positivos estejam realmente infectados, em decorrência das elevadas sensibilidade e especificidade dos testes em série empregados (AATe2-ME), em torno de $95 \%$ e 99,5\%, respectivamente (AzEVEDo, 2006). Este protocolo vem sendo utilizado oficialmente no Brasil para o diagnóstico sorológico da brucelose bovina como parte integrante das ações do Programa Nacional de Controle e Erradicação da Brucelose e Tuberculose Bovina (PNCEBT), instituído em 2001.

Osresultadosobtidosnopresentetrabalholevantam preocupações, pois suínos soropositivos para a bruceloseestão sendoencaminhados para abate, expondo os magarefes ao risco ocupacional. Dessa forma, éimportante a adoção de algumas medidas preventivas, como o uso de luvas para manejar esses animais, bem como outras medidas de biossegurança necessárias. Além disso, é necessário que haja um trabalho comunitário de esclarecimento para proprietários, tratadores e magarefes, bemcomo paralideranças decomunidades, agentes de saúde animal e consumidores.

Apesar de a infecção de suínos por B. abortus ser considerada ocasional, há a possibilidade dos animais reagentes no presente trabalho serem positivos para essa espécie, pois pode haver reação cruzada nos testes empregados (OIE, 2009). Dessa maneira, essa hipótese levanta preocupações com relação ao Programa Nacional de Controle e Erradicação da Brucelose e Tuberculose Bovina (PNCEBT), uma vez que suínos infectados por $B$. abortus podem eliminar o agente e expor bovinos ao risco de infecção, comprometendo, assim, o sucesso do programa.

Tabela 1 - Frequência e intervalo de confiança de 95\% de anticorpos contra brucelas lisas em suínos abatidos no semiárido da Paraíba, no período de abril a junho de 2007, segundo o sexo dos animais.

\begin{tabular}{lccccccc}
\hline \multirow{2}{*}{ Sexo } & \multicolumn{3}{c}{ Antígeno Acidificado Tamponado } & & \multicolumn{3}{c}{ 2-mercaptoetanol } \\
\cline { 2 - 4 } & $\mathrm{N}$ & Frequência (\%) & IC 95\% & & $\mathrm{N}$ & Frequência (\%) & IC 95\% \\
\hline Macho & $1 / 124$ & 0,81 & $0,02-4,41$ & & $0 / 124$ & 0,00 & $0,00-2,93$ \\
Fêmea & $2 / 182$ & 1,10 & $0,13-3,91$ & & $2 / 182$ & 1,10 & $0,13-3,91$ \\
\hline Total & $3 / 306$ & 0,98 & $0,20-2,84$ & & $2 / 306$ & 0,65 & $0,08-2,34$ \\
\hline
\end{tabular}




\section{REFERÊNCIAS}

ALTON, G.G. Brucella suis. In: NIELSEN, K.; DUNCAN, J.R. (Ed.) Animal brucellosis. Boca Raton: CRC Press, 1990. cap.18, p.411-422.

AZEVEDO, S.S. Caracterização epidemiológica da brucelose bovina no Estado do Espírito Santo. 2006. 103f. Tese (Doutorado em Medicina Veterinária - Área Epidemiologia Experimental de Aplicada às Zoonoses) - Universidade de São Paulo, São Paulo, 2006.

BRASIL. Ministério da Agricultura, Pecuária e Abastecimento. Departamento de Defesa Animal. Programa Nacional de Controle e Erradicação da Brucelose e Tuberculose Animal (PNCEBT). Inquérito soroepidemiológico da brucelose - Manual de procedimentos. Brasília: MAPA/ SDA/DDA, 2001. 20p.

CRAWFORD, R.P.; HUBER, J.D.; ADAMS, B.S. Epidemiology and surveillance. In: NIELSEN, K.; DUNCAN, J.R. (Ed.). Animal brucellosis. Boca Raton: CRC Press, 1990. cap. 7, p.131-151.

FREITAS, J.A.; GALINDO, G.A.R.; SANTOS, E.J.C.; SARRAF, K.A.; OLIVEIRA, J.P. Risco de brucelose zoonótica associado a suínos de abate clandestino. Revista de Saúde Pública, v.35, n.1, p.101-102, 2001.
GODFROID, J.; KÄSBOHRER, A. Brucelosis in the European Union and Norway at the turn of the twentyfirst century. Veterinary Microbiology, v.90, p.135-145, 2002.

MATOS, M.P.C.; SOBESTIANSKY, J.; PÔRTO, R.N.G.; MEIRINHOS, M.L.G. Ocorrência de anticorpos para Brucella sp. em soros de matrizes suínas de granjas que abastecem o mercado consumidor de Goiânia, Estado de Goiás, Brasil. Ciência Animal Brasileira, v.5, n.2, p.105108, 2004.

OIE - WORLD ORGANIZATION FOR ANIMAL HEALTH. Porcine brucellosis. Manual of standards for diagnostic tests and vaccines for terrestrial animals. 2009. Disponível em: <http:/ / www.oie.int/eng/normes/mmanual>. Acesso em: 30 mar. 2009.

ROXO, E.; BERSANO, J.G.; PORTUGAL, M.A.S.C. Brucella suis em diversas espécies de animais numa mesma propriedade rural. Arquivos do Instituto Biológico, São Paulo, v.63, n.l, p.11-14, 1996.

ZAR, J.H. Biostatistical analysis. 4.ed. Upper Saddle River: Prentice Hall, 1999. 663p.

Recebido em 9/9/10

Aceito em 22/11/11 